\title{
Experiencias
}

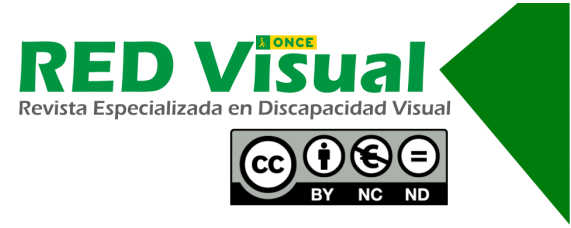

\section{Conjunto de actividades basadas en el desarrollo multisensorial y la alfabetización en braille y tinta para favorecer la inclusión educativa en Primaria de un alumno con discapacidad visual}

\author{
Suite of activities based on multi-sensorial development and Braille \\ and inkprint literacy to favour inclusion of a primary school student \\ with visual disability \\ O. Urdangarin Iriarte
}

\section{Resumen}

Este trabajo muestra una experiencia de enseñanza-aprendizaje, incluyendo en un aula de Educación Primaria a un alumno con baja visión, con el campo visual afectado y cuyo pronóstico exige el aprendizaje del braille. Para ello, se presentan actividades de alfabetización en los dos códigos (braille y tinta), de estimulación sensorial, habilidades hápticas, de ajuste personal y social y que favorecen la inclusión. Todas ellas están fundamentadas con la normativa y las teorías más actuales, y están realizadas con mucha implicación emocional por parte de todos los agentes que han intervenido, donde jugar, pillar por sorpresa, emocionar, apoyar, retar y divertirse aprendiendo han ayudado a motivar y a seguir adelante pese a la fatiga y al tropezón.

\section{Palabras clave}

Motivación. Inclusión. Braille. Estimulación sensorial. Ajuste a la discapacidad visual.

\begin{abstract}
This article describes a teaching-learning experience involving inclusion of a primary school student with an impaired visual field and a prognosis that would eventually necessitate a

Urdangarin, O. (2020). Conjunto de actividades basadas en el desarrollo multisensorial y la alfabetización en braille y tinta para favorecer la inclusión educativa en Primaria de un alumno con discapacidad visual. RED Visual: Revista Especializada en Discapacidad Visual, 76, 115-148. https://doi.org/10.53094/OSKU2586.
\end{abstract}


command of braille. The activities undertaken to teach him to read in both codes (braille and inkprint) are discussed, including sensorial stimulation, haptic skills and personal and social adjustment to favour inclusion. All, based on the existing legislation and most current theories, were implemented with considerable emotional investment on the part of the agents involved, where playing, surprising, eliciting emotion, supporting, challenging and amusing drove motivation and helped carry on despite fatigue and error.

\section{Key words}

Motivation. Inclusion. Braille. Sensorial stimulation. Adjustment to visual disability.

\section{Presentación y justificación}

Se presenta el trabajo realizado con una persona de baja visión y su grupo-clase de primer curso de Educación Primaria. La tarea principal de la profesora de apoyo ha sido desarrollar y reforzar las competencias básicas e introducir contenidos concretos de enseñanza y aprendizaje, tales como el braille, el desarrollo de los sentidos y el ajuste personal y social.

Se trata de una buena práctica inclusiva, guiada por principios, objetivos, procedimientos creativos y pautas adecuadas a una normativa, a teorías y a ciencias sólidas y contemporáneas que serán explicadas a continuación.

Pero, sobre todo, ha sido, por una parte, una respuesta educativa con buen asesoramiento por parte del Centro de Recursos de Educación Especial de Navarra, equipo de visuales (Creena), y su Unidad de Apoyo Educativo (UAE). Y por otra, una experiencia positiva, motivadora y gratificante, con mucha implicación emocional por parte de todos los participantes.

Los argumentos para justificar esta buena práctica son los siguientes: se basa en leyes y derechos sobre la discapacidad visual y la educación; es eficaz porque se ha valorado con criterios la puesta en la práctica y contiene pilares tan importantes como la inclusión, motivación, participación y autonomía e independencia personal del alumnado y la comunidad educativa; realiza aportaciones innovadoras teniendo en cuenta teorías y ciencias de aprendizaje muy actualizadas, y su práctica en el ámbito educativo puede ser extensible a cualquier centro que incluya a alumnado con baja visión o discapacidad visual. 
A continuación, se hace una aclaración de cada argumento.

\section{La respuesta educativa es igual al derecho y la obligación}

Esta práctica docente resuelve una respuesta educativa a raíz de la detección de necesidades de alfabetización en un niño con discapacidad visual, la cual se entiende como un derecho y una obligación, dado que las leyes vigentes de educación y los derechos de las personas con discapacidad de España lo amparan.

El sistema educativo español, establecido por la LOE en los artículos 1 y 2 (Ley Orgánica 2/2006, de 3 de mayo, de Educación), y la Lomce en su artículo único (Ley Orgánica 8/2013, de 9 de diciembre, para la mejora de la calidad educativa) explican el principio de calidad de la educación para todo el alumnado, independientemente de sus condiciones y circunstancias, y la equidad que garantice la igualdad de oportunidades, la inclusión educativa y la no discriminación. Además, la Convención sobre los derechos del niño (Unicef, 2006) exige a todos los países participantes, España incluida, que la educación actúe como elemento compensador de las desigualdades personales, culturales, económicas y sociales, con especial atención a las que deriven de discapacidad.

La Convención sobre los Derechos de las Personas con Discapacidad, ratificada en España el 23 de noviembre de 2007, asegura «que la educación de las personas, y en particular los niños y las niñas ciegos, sordos o sordociegos se imparta en los lenguajes y los modos y medios de comunicación [por ejemplo, el braille] más apropiados para cada persona y en entornos que permitan alcanzar su máximo desarrollo académico y social» (Instrumento de Ratificación de la Convención sobre los derechos de las personas con discapacidad, hecho en Nueva York el 13 de diciembre de 2006, 2008; art. 24, 3, c)).

\section{Ha sido eficaz: inclusión, motivación, participación y autonomía}

Después de un año de experiencias, se puede decir que la eficacia de esta respuesta no solo se prueba con los resultados obtenidos, sino también con ciertos puntos claves de la metodología utilizada. En otras palabras, por «el asesoramiento actualizado y preciso, desde el principio, del Equipo Específico de Atención a personas con discapacidad visual» (Creena).

Se trata de un asesoramiento interdisciplinar con una formación actualizada y que colabora, sobre todo, con la Organización Nacional de Ciegos Españoles (ONCE) y con

Urdangarin, O. (2020). Conjunto de actividades basadas en el desarrollo multisensorial y la alfabetización en braille y tinta para favorecer la inclusión educativa en Primaria de un alumno con discapacidad visual. RED Visual: Revista Especializada en Discapacidad Visual, 76, 115-148. https://doi.org/10.53094/OSKU2586. 
la orientadora y la profesora de apoyo del centro, pero también en algunas ocasiones, con los progenitores del afectado.

Sus aportaciones teóricas han sido siempre muy actualizadas, basadas en inclusión, en aprendizaje significativo, en neurociencia y psicología positiva. Las pautas de actuación que ofrecen sobre movilidad y seguridad, estimulación del resto visual, adaptaciones, ajuste personal, estrategias de lectura y escritura se adaptaron a las necesidades educativas reales del alumnado. Estas han ofrecido una gran variedad de materiales, a veces, incluso muy novedosas. Y, sobre todo, la implicación emocional, el apoyo incondicional (en cada duda) y la cercanía han sido muy importantes para una tarea difícil desde el principio.

Con respecto a las actuaciones didácticas y metodológicas realizadas que siempre persiguen la inclusión, se tuvo claro desde el principio que se tenía que trabajar la discapacidad visual desde una perspectiva inclusiva, no solo con el niño sino también con su entorno, su grupo-clase, su familia y, en definitiva, con toda la comunidad educativa. Por eso, se han realizado charlas de sensibilización, seminarios que ofrece la ONCE, adaptaciones de acceso y formación para el profesorado.

En todas las actividades que se han realizado siempre se ha garantizado el éxito y el placer de experimentar y de aceptar y respetar el ser diferentes. Nos ayudaron a organizar bien nuestro trabajo inclusivo las indicaciones de Cauto (2016).

En cuanto a intentar siempre conseguir un aprendizaje significativo, motivación, participación y autonomía, la experiencia de cientos de profesionales en las últimas décadas sostiene que el aprendizaje significativo (Piaget, Vigotsky), el que sirve para la vida, el que se mantiene en el tiempo, se aprende desde el deseo y la motivación, desde la participación activa del alumnado en el propio aprendizaje, desde el autoconocimiento y el ajuste personal.

Por su parte, en relación a la motivación, se considera que para conseguir un aprendizaje significativo, «es preciso conseguir en el alumno la implicación emocional, dirigida tanto hacia el objeto de aprendizaje [...] como hacia la persona que guía su aprendizaje» (Comisión Braille Española, 2015).

Además, en este trabajo, de acuerdo con la participación, la autonomía y el autoconocimiento, se han seguido pautas educativas que, desde la neurodidáctica (Spitzer,

Urdangarin, O. (2020). Conjunto de actividades basadas en el desarrollo multisensorial y la alfabetización en braille y tinta para favorecer la inclusión educativa en Primaria de un alumno con discapacidad visual. RED Visual: Revista Especializada en Discapacidad Visual, 76, 115-148. https://doi.org/10.53094/OSKU2586. 
2005) y la psicología positiva de Golden5 (Lera, 2009), se han recomendado por ser eficaces para despertar el deseo de aprender y conseguir permanencia.

A este respecto, es muy importante que el alumno con discapacidad sea el centro del aprendizaje y participe de forma activa en él. Los métodos a utilizar deben ser respetuosos con la metodología y didáctica que una persona con discapacidad visual necesita.

Este niño, en concreto, precisa desarrollar aprendizajes previos a la enseñanza del código braille, habilidades básicas que exigen dedicar tiempo y esfuerzo, pero que son imprescindibles y que están relacionadas, entre otras, con su madurez mental y psicomotriz, motivación, funciones ejecutivas, desarrollo háptico y habilidades lingüísticas. No es solamente hacer una adaptación de acceso.

Asimismo, tal y como propone la neurociencia, se debe favorecer el desarrollo del autoconocimiento y la autonomía para llegar al desarrollo de las funciones ejecutivas (o para aprender a aprender), es decir, aquellas habilidades cognitivas que permiten a la persona lograr un objetivo o resolver un problema, de forma planificada y lógica (Hannan (2006), citado por Comisión Braille Española (2015)). A veces hay que trabajar estas habilidades para poder conseguir un aprendizaje significativo, aquel que no se olvida.

Es muy importante el trabajo realizado de ajuste personal de la discapacidad, ya que cuanto antes se comience a trabajar, mejores beneficios traerán para el propio alumno, pudiendo ayudar también a los demás niños de la clase, porque propicia una diversidad funcional y, en definitiva, una inclusión mucho más positiva.

\section{Con aportaciones innovadoras: neurodidáctica}

Otra de las razones por las que se puede decir que es una buena práctica es que puede aportar ideas novedosas que ayudan a que el trabajo diario de aprendizaje sea más ameno, más manipulativo y creativo.

Todos estos materiales, actividades, metodologías y decisiones tomadas para la alfabetización del alumnado con discapacidad visual están basadas en neurodidáctica (Preiss Gerard) y más concretamente, en el libro La didáctica del braille más allá del código (Comisión Braille Española, 2015) sobre los últimos métodos para la enseñanza del braille. 


\section{Alcance de trabajo extenso}

Este trabajo es extrapolable a cualquier centro educativo con alumnado que tiene una discapacidad visual, baja visión, y precise aprender braille además del código tinta, es decir, esté en la primera o segunda etapa de la alfabetización de la lectura y escritura o de la enseñanza del braille.

Tanto los materiales como las actividades también dan la posibilidad de poderse utilizar de forma independiente para alumnado con baja visión y para los demás alumnos de forma inclusiva, y que, de esa manera, se puedan aplicar también en cualquier centro educativo ordinario.

\section{Método}

Tal y como se ha explicado en la justificación de esta práctica, la metodología está basada en teorías de la educación contemporánea que favorecen el aprendizaje significativo y tienen en cuenta las necesidades educativas especiales derivadas de la discapacidad visual, en ciencias como la neurodidáctica y, sobre todo, en la inclusión.

\subsection{Población destinataria de la experiencia}

El alumno con el que se ha puesto en práctica esta experiencia presenta un diagnóstico de baja visión con afectación del campo visual. Ha accedido, junto con sus compañeros de clase, a la lectoescritura en tinta; por lo tanto, utiliza este código lector en las actividades de clase. Sin embargo, teniendo en cuenta el pronóstico de dicho diagnóstico, se ha decidido introducir el código braille de forma lúdica.

Por una parte, esta experiencia es adecuada para cualquier niño matriculado en Educación Primaria que tiene baja visión y al que se decide enseñar el braille como una alternativa más para conseguir su desarrollo integral y autónomo para la vida.

Aunque parezca que la cantidad de niños y niñas que reciben esta ayuda es insignificante, según la web oficial de la Organización Mundial de la Salud (2018), estamos hablando de aproximadamente un $17,5 \%$ de los niños de $0-14$ años en el mundo. El Instituto Nacional de Estadística [INE] (2008) y Gómez-Ulla (2012), referidos en la 
página web de Matías Sánchez (Sánchez, 2015), añaden que 920.900 personas tienen baja visión, y de estas aproximadamente 45.000 son niños.

Pero, por otra parte, por su carácter inclusivo, esta experiencia no solo va a contribuir a responder a la población de baja visión que va a aprender braille, sino también a alumnado de primero de Primaria y a la comunidad educativa en general. Por tanto, se habla de una población más amplia todavía.

Esta práctica educativa se realizó durante el curso 2017-2018 con una duración de 10 meses, desde septiembre a junio.

\subsection{Objetivos}

1. Desarrollar el resto visual.

2. Desarrollar los demás sentidos, experimentar con ellos.

3. Desarrollar la percepción háptica y la motricidad, tanto fina como gruesa.

4. Desarrollar algunos prerrequisitos para el braille: enriquecer el lenguaje oral, desarrollar el esquema corporal, exponer al niño a la mayor cantidad de estímulos en braille.

5. Aprender letra a letra la lectoescritura en tinta.

6. Aprender letra a letra la lectoescritura en braille.

7. Avanzar en el desarrollo emocional y el ajuste personal y social.

8. Sensibilizar y hacer partícipe a la comunidad educativa de los logros y las dificultades de esta población de forma inclusiva.

9. Avanzar en la adquisición de las competencias que corresponden para su edad. Reforzar y adaptar si fuese necesario.

10. Gestionar la fatiga y la implicación emocional, «estimular sin saturar, ayudar sin invadir» (Comisión Braille Española, 2015). 
En un primer vistazo, llevar a cabo 10 objetivos durante un curso puede parecer muy difícil, pero el centro lleva trabajando los cuatro primeros desde el curso pasado, y, por lo tanto, no se realizan de forma tan sistemática.

Al objetivo 10 se le ha tenido en cuenta en todas y cada una de las sesiones directas e indirectas que se han llevado a cabo, y esto ha supuesto una retroalimentación y reorientación continuas.

En el Apéndice A se expone la relación de objetivos educativos antes descritos, las actividades realizadas, el número de sesiones y las aulas utilizadas.

\subsection{Plan de trabajo}

El plan de trabajo realizado se ha llevado a cabo con el asesoramiento por parte del Módulo de Discapacidades Visuales del Centro de Recursos de Educación Especial de Navarra (Creena, 2020). Uno de los libros mencionados por su parte fue el de Albertí y Romero (2010), el cual, en líneas generales, ayuda a comprender mejor a un alumno con baja visión y a comenzar a conocer la intervención dentro y fuera del aula.

Desde el Departamento de Educación y el Creena, se decidió que se iba a dotar de 7 sesiones de profesora de apoyo para que se pudieran atender las necesidades de este niño con baja visión, de las cuales 2 fueron de atención indirecta para adaptar material y la coordinación familia-escuela.

El resto se utilizó para conseguir los objetivos atendiendo al alumno de forma directa, 5 en total: en 3 sesiones se trabajaba dentro del aula, reforzando los aprendizajes y se cumplía con los objetivos más inclusivos (7 y 8). En las otras 2 sesiones se trabajaba en el aula de apoyo y los objetivos que requerían un entrenamiento más individualizado (de 1 a 6 ).

En cada sesión directa, en el aula de apoyo, normalmente se trabajan 3 actividades, no recomendándose más porque muchas veces estas actividades necesitan una reflexión o una explicación de lo ocurrido en presencia y con la participación de la alumna o alumno para ir mejorando.

Para realizarlas en 50 minutos, se deja de antemano el aula preparada. Siempre se presentaban las actividades mediante una caja de actividades o un sobre pegado en

Urdangarin, O. (2020). Conjunto de actividades basadas en el desarrollo multisensorial y la alfabetización en braille y tinta para favorecer la inclusión educativa en Primaria de un alumno con discapacidad visual. RED Visual: Revista Especializada en Discapacidad Visual, 76, 115-148. https://doi.org/10.53094/OSKU2586. 
la ventana del cristal que hacía referencia al reto. De esta manera, la motivación e implicación emocional aumentaban.

\subsection{Actividades y materiales nuevos}

Se presentan las actividades que se han realizado durante este curso para trabajar los objetivos antes descritos. Estas actividades están clasificadas en grupos y, en total, hay siete. Cada grupo de actividades se desarrolla en un cuadro y contiene un título y una descripción (ver Cuadros del 1 al 7).

Al final de este documento, en el Apéndice B, se encuentra una guía de materiales para poder confeccionar y crear las actividades contenidas en los Cuadros del 1 al 7, así como una selección de imágenes de los materiales más representativos.

\section{Cuadro 1. Actividades de ajuste personal y desarrollo emocional}

\section{Grupo de Actividades 1 \\ Actividades de ajuste personal y desarrollo emocional}

Actividades que surgen en casa, en el aula ordinaria o en la escuela, de forma espontánea, por situaciones que se han vivido y experimentado en las que la discapacidad visual influye.

Las tareas principales son las siguientes:

- Facilitar y promover el conocimiento progresivo de su situación visual, de sus posibilidades y repercusiones.

- Propiciar formas de afrontamiento positivo de las repercusiones que se derivan de sudéficit visual.

- Se trabajan las estrategias explicadas en la formación recibida sobre ajuste personal por parte del Centro de Recursos de Educación Especial de Navarra (Creena, 2020).

El método que se utiliza es el siguiente:

- Detectar la situación. En el aula hay un pequeño hueco diseñado para hablar y sentirse bien. 
- Se pide al niño que exprese lo que le ocurre, es decir, la situación que ha vivido, cómo se ha sentido, qué hipótesis tiene de por qué ha surgido ese problema o dificultad. Para ello, es imprescindible un buen ambiente de seguridad y confianza, estrategias de escucha activa y análisis de la situación (saber los pensamientos que ha generado esa situación, las emociones con las que ha vivido y los comportamientos que le han generado).

- La mayoría de las veces, los pensamientos que genera esa situación son los agravantes de la situación. Lo que siempre se intenta es ajustar esos pensamientos o buscar otro tipo de pensamientos más realistas. A veces, simplemente ofreciendo un abanico de hipótesis, otras veces hablando con el resto de personas que conocen la situación e intentando buscar los hechos y causas reales. Para ello, es muy importante aceptar las emociones y los comportamientos que ha tenido.

- Al final, se intenta buscar la forma más adecuada del alumno para abordar la situación o el problema, es decir, se intenta buscar soluciones, probarlas o llevarlas a cabo, esperar un tiempo y hacer un seguimiento para saber si se han conseguido o no solucionarlos. A veces, también, se hacen juegos, se cuentan cuentos que ayudan a mejorar la situación o que ayudan a generar soluciones positivas.

- Estás pautas están basadas en el proceso de ajuste a la discapacidad visual y las propuestas de orientaciones de intervención planteadas por Salabert y Pallero (2003).

- Las situaciones que surgieron en este curso son:

- «Tengo miedo a los pollitos (porque se mueven todo el rato, los pierdo de vista y me ponen nervioso)».

- «Tengo miedo a la oscuridad (porque no puedo ver nada, me puedo tropezar)».

- «En el patio me quedo solito (y creo que es porque nadie quiere jugar conmigo o porque los pierdo de vista)».

En esta última, el alumnado se comprometió a ponerse unos petos con colores chillones para que el alumno con baja visión pudiera encontrarlos con más facilidad en el patio. Pero, antes de esta solución, se probaron otras, lo que quiere decir que no siempre se encuentra el abordaje más eficaz a la primera. 


\section{Grupo de Actividades 2 Actividades que favorecen la inclusión}

Son 3 actividades que se realizan al final de cada trimestre o evaluación. Nacen de la necesidad, por parte de su grupo-clase, de saber qué trabajamos o a qué jugamos, y por la motivación e iniciativa propia del niño con discapacidad visual.

- El alumno con baja visión elige y decide algunas de las actividades realizadas durante el trimestre. Después, con la ayuda del adulto, organiza el aula y lo muestra a su grupo-clase.

- El alumno explica la forma de jugar o realizar cada actividad, e incluso hace una demostración. Los demás prueban y juegan durante un tiempo.

- Luego explican cómo se han sentido, qué les ha gustado más o menos. El objetivo es sensibilizar a la población y experimentar lo que esta población vive cada día.

- Se grabaron y se mostraron a las familias de los participantes las actividades realizadas con ellos.

Actividades realizadas:

- Experimentamos con las gafas: el alumnado se pone gafas que simulan enfermedades diferentes (la visión no es buena) y tienen la oportunidad de poder andar dentro del aula y en el patio. La actividad del patio se hace por parejas y se valora la ayuda aportada.

- Taller de los sentidos: se realiza una exposición de actividades para desarrollar los 5 sentidos. El alumnado podrá probar cuál es su mejor sentido y la dificultad a veces de realizarlo con los ojos tapados. Se aprovechó también para resaltar los beneficios que tenía el trabajar todos los sentidos.

- Brailleando: se plantean diferentes actividades de percepción háptica para que los niños puedan entender para qué sirve. El alumno muestra a sus compañeros el libro que explica lo que es el braille y otros materiales táctiles para que lo puedan tocar y utilizar. Al final, el alumno mostró cómo había aprendido a leer el nombre de sus compañeros y regaló a cada alumno el nombre escrito en braille. 


\section{Grupo de Actividades 3 \\ Trabajando el resto visual: observamos y rastreamos}

Se trata de un conjunto de actividades y materiales que ayudan a estimular el resto visual.

- Caja de láminas de observación: láminas de imágenes y preguntas, poesía visual (imágenes en blanco y negro) y disparates obtenidos en internet mediante buscadores de imágenes. El objetivo, en este caso, también es realizar el rastreo y contestar a las preguntas que se hacen o encontrar el disparate.

- Cartas de memory: hay dos imágenes casi iguales en forma de carta, pero tienen una diferencia o dos, como mucho. Por ejemplo, el gesto de la cara (enfadado/ contento).

- Buscamos la pareja de los colores: el juego consiste en encontrar la pinza de color exacta al rango de color que aparece en la caja.

- Formas: con palos de helado y velcro, se hacen formas planas, y con palillos y plastilina intentamos construir la misma figura expuesta en 3D. Puede tocar y ver el modelo desde distintas perspectivas.

- Imitaciones: se trata de que el adulto realice un movimiento con una parte del cuerpo y el niño realice el mismo.

\section{Grupo de Actividades 4 Experimentación con los 5 sentidos}

Se realiza 2 veces al mes y dura 15 minutos. El objetivo es ejercitar o desarrollar los sentidos mediante el juego. Este curso hemos trabajado más el tacto y la audición. Son juegos sencillos pero muy divertidos. Al final de cada actividad se habla de las sensaciones y de lo que se puede captar con cada sentido.

Muchas de las actividades realizadas se han encontrado en el libro de juegos de Silberg (2006), pero se pueden encontrar muchos más de discriminación auditiva o estimulación auditiva en internet. 


\section{Grupo de Actividades 5 Estimulación de la percepción háptica}

Además de poner en práctica otras tareas y recomendaciones que dan para trabajar la percepción háptica, se han creado 2 actividades más:

- Caja de sorpresas: se trata de un escenario de marionetas pequeño, pero con forma de caja y una cortinilla. El adulto y el alumno se ponen a la par. El adulto ofrece al alumno, que tiene puesto un antifaz, diferentes elementos, y el alumno debe adivinar de lo que se trata. Estos elementos estaban relacionados con los proyectos que se trabajaban (Ciencias Naturales y Sociales). Es decir, si se trataban los dinosaurios se añadían otros animales para trabajar la discriminación. Al mismo tiempo, se ampliaba el vocabulario.

Con el tiempo y la práctica se han ampliado los objetivos: si en un principio no ayudaba a discriminar objetos mediante tacto, nos pareció muy interesante para trabajar las representaciones mentales de los objetos. Cuando se intenta por primera vez discriminar de forma táctil, se puede llegar a una representación mental de lo que tocamos. El objetivo principal es llegar a memorizar esas representaciones mentales para que luego puedan automatizarse en la vida diaria.

Se utilizan piezas de Lego, comenzando con las de Lego Duplo (de mayor tamaño) y seguidamente las de Lego Junior (el tamaño estándar). El juego consiste en crear una estructura con bloques (primero se comienza con 4 fichas y después se va ampliando el número de bloques), de manera que el alumno realice una discriminación háptica $y$, con los bloques que tiene a su derecha, realice la misma estructura. Es una actividad muy gratificante para el alumnado.

- La bandeja de los tesoros: se trata de acostumbrarse a palpar diferentes texturas táctiles. Para ello, en una bandeja se coloca un material (hierba, hojas, arena, nata, gelatina, leche, cola, harina, azúcar, sal, tierra, papeles, telas, agua caliente, agua fría...) y dentro se colocan papeles con palabras escritas y objetos pequeños o comida. El alumnado, con los ojos tapados, debe encontrar los elementos, pero también debe averiguar de qué material se trata, y para ello tiene que utilizar siempre los sentidos y seguir los pasos para realizar una percepción háptica adecuada. A veces, los mensajes o figuritas iban escondidos en los botes de los huevos Kinder.

Los papeles encontrados se leen, siendo palabras que tienen que ver con el vocabulario aprendido de cada proyecto, alguna chuchería o figurita pequeña. Alguna vez, se llega a hacer un mapa conceptual con esos papelitos encontrados. 


\section{Grupo de actividades 6 Motricidad fina: libros y láminas táctiles}

Se trata de una actividad muy creativa realizada al finalizar cada proyecto. El alumno plasma un cuento o una lámina explicativa de lo aprendido, y, para ello, debe probar texturas, elegir materiales, recortar, pegar, moldear...

Debe señalarse que fue de gran ayuda haber trabajado con cuentos de texturas cedidos por el Creena, como, por ejemplo, El caracol Serafín, La pulga Leocadia o cuentos de los materiales de Braitico. En este sentido, pueden consultar los apartados de «Recursos educativos: cuentos y juegos» (ONCE, 2020b) y de Braitico (ONCE, 2020a; ONCE, 2018), ambos en la web de Educación de la ONCE.

De este modo, se han creado:

- El cuento de la vida de los dinosaurios y la máquina del tiempo.

- El cuento de los hombres primitivos.

- Láminas explicativas sobre la digestión de los humanos.

- Láminas explicativas sobre los huesos del cuerpo humano.

- Teatro de sombras sobre romanos y griegos. Dibujamos y creamos las marionetas para hacer el Teatro de Troya.

En las láminas se meten el nombre de algunos huesos u órganos en braille.

Cuadro 7. Actividades para el aprendizaje de lectoescritura en tinta y braille

\section{Grupo de Actividades 7 \\ Lectoescritura: letra a letra en tinta y braille}

Por el diagnóstico de baja visión con afectación del campo visual, y, sobre todo, por su pronóstico, se decidió que mientras comenzaba el aprendizaje en tinta de la lectoescritura también se comenzase con la enseñanza del braille, entendiendo siempre a este último como una segunda alternativa.

Ha sido de gran ayuda Sánchez (2005) para comprender cómo iba a ser el proceso de aprendizaje en tinta de este alumno con baja visión en líneas generales

La enseñanza de la lectoescritura en braille debía de ser algo muy ameno, porque la lectoescritura ya causaba gran fatiga en el alumno con discapacidad visual. Por eso, se 
diseñaron actividades lo más lúdicas posibles pero que se garantizase el aprendizaje del braille. Las actividades siguientes se han realizado 2 veces por semana y de manera sistemática, puesto que podrían crearse errores de memorización.

Se decidió que el orden de las letras iba a ser el mismo que se utiliza para enseñar la lectura y escritura en tinta en el aula ordinaria, es decir, método analítico Dilin-Dalan («a, e, i, o u, m, t, k...»). Los objetivos principales eran los siguientes:

- Aprender las letras en tinta y memorizarlas, para poder leer y escribir palabras y frases con soltura y de manera autónoma.

- Aprender las letras en braille y memorizarlas, y, en este caso, memorizar significa que el niño tenga una representación mental de cada letra, de cada cajetín (la colocación de los puntos en cada letra). Se incidía mucho con el tema de simetría de las letras en braille una vez que aprendíamos la segunda letra en discordia.

- Aprender a combinar las letras de braille para formar palabras (se comenzó con los nombres de los compañeros y después se empleó el vocabulario de cada letra, el mismo de tinta).

- Aprender a leer letras y alguna palabra en braille (muy sencillas) y diferenciar los espacios y las palabras.

La caja de las letras: letra a letra en tinta/braille. Con objetos que se traen de casa, del patio, del aula ordinaria o que se consiguen en las bandejas de textura, se creaba la «caja marrón». El objetivo era escribir en tinta o leer palabras que contenían al principio, en la mitad o al final la letra que se estaba aprendiendo. Por tanto, con chicle se pegaba el objeto en la caja, y al lado, con papelitos o pósit, se escribía la palabra en tinta.

A partir de la letra «p» se comenzó también a escribir en braille la palabra y a colocarla en la caja (en este caso, el alumno debía intentar tocar y averiguar las letras que había de forma háptica, y así descifrar la palabra y el objeto). Para ello, al principio, se utilizaron como ayuda los monstruos azules y los coches, que se explican a continuación. En las últimas letras se utiliza la máquina braille para escribir palabras y que, de forma háptica y letra a letra, se pudiera descubrir la palabra.

Esta caja se compartía con la clase una vez que finalizábamos. El alumnado de su clase estaba realizando un mini diccionario de palabras y nosotros también aportábamos nuestras palabras (a veces en tinta y otras en braille/tinta).

Método Guberina: este método de lectoescritura une el sonido y el gesto de cada letra. Se ha utilizado en clase como refuerzo, puesto que los alumnos, conforme iban aprendiendo las letras, se confundían u omitían letras. En concreto, al alumno con baja visión le ayudaba y le daba seguridad a la hora de escribir de forma espontánea. Pero, en las

Urdangarin, O. (2020). Conjunto de actividades basadas en el desarrollo multisensorial y la alfabetización en braille y tinta para favorecer la inclusión educativa en Primaria de un alumno con discapacidad visual. RED Visual: Revista Especializada en Discapacidad Visual, 76, 115-148. https://doi.org/10.53094/OSKU2586. 
clases de apoyo, se incidía mucho en que se aprendieran bien los gestos de la letra, porque a veces no se habían asimilado de forma correcta. Hoy en día todavía tiene confusiones y sigue utilizando dicho método para corregirlos.

Carpeta de coches y monstruos de colores. Esta carpeta ha ido creándose durante todo el curso. Por cada letra contiene una tarjeta que simula, mediante círculos con diferente textura, a cinco familiares y el alumno con discapacidad visual en un coche. A veces no todos los miembros de la familia pueden viajar en el coche, por lo que faltan círculos con textura. De esta forma comenzamos a simular cada cajetín del braille.

Una vez que aprendió 3 letras, se comenzó a jugar. Los coches, si están quietos en el garaje (en la carpeta), se estropean y, además, a veces algunas personas tienen que ir a hacer recados, por lo que esos coches deben salir. El soporte donde se colocan las tizas era la carretera, y en la pizarra se dibujaban tiendas o paisajes, por lo que el coche daba una vuelta. Había que fijarse bien quién iba de paseo para luego presionar los botones del muñeco Braillín. De esta forma, se memorizaba cuántos puntos salientes tenía la letra y en qué orden estaban situados. Y, poco a poco, se ha ido memorizando el alfabeto braille.

Estos coches resultaban demasiado grandes después para juntarlos y no muy prácticos para tocarlos, por lo que, cuando se comenzó con la letra «g», se introdujeron los monstruos azules.

Se trata de pequeños monstruos con muchos ojos, hasta 6 puede tener. A estos monstruos no les gusta estar solos y siempre van en compañía. Se debe tener en cuenta el orden en el que aparecen los ojos para descifrar la letra o la palabra. A veces, un grupo de monstruos azules aparecían en el sobre de los retos y otras veces se sacaban de las carpetas para escribir las palabras en braille de la caja de las letras. De esta forma, se empezaban a construir palabras en braille.

Con los monstruos azules se ha incidido mucho en el tema de la simetría y se ha intentado que, de forma táctil, tengan muy clara la identificación de cada letra. El material de braille Miniforms ha sido muy útil para trabajar este concepto.

Se podían escribir con máquina Perkins o colocar los dedos en Maripoints para saber cómo se escribe.

Adaptación de materiales Braitico (Palabritas y Contando; Organzación Nacional de Ciegos Españoles (2020a)): estos dos pequeños cuadernos recomendados por el equipo específico se han utilizado mucho, pero se han adaptado en los dos casos, haciendo desaparecer los números y letras en tinta, dado que a veces resultaba muy incómodo tener que taparse los ojos todo el rato. En lo que respecta a Contando, se creó otro material similar que trabaja los números del 1 al 100 (con tarjetas y regletas). Con este material, los niños deben encontrar de forma táctil la letra intrusa o deben encontrar el número o la cantidad.

Urdangarin, O. (2020). Conjunto de actividades basadas en el desarrollo multisensorial y la alfabetización en braille y tinta para favorecer la inclusión educativa en Primaria de un alumno con discapacidad visual. RED Visual: Revista Especializada en Discapacidad Visual, 76, 115-148. https://doi.org/10.53094/OSKU2586. 


\title{
2.5. Recursos espaciales, personales y nuevas tecnologías
}

\author{
Recursos espaciales
}

Para llevar a cabo todas las actividades se han utilizado diferentes aulas. A veces, los objetivos marcados exigen espacios y materiales diferentes, de manera que el alumno con discapacidad visual debe tener la posibilidad de experimentar en diferentes ambientes.

Durante 2 o 3 sesiones semanales se ha utilizado el aula de apoyo. El aula estaba adaptada a las necesidades del alumno con baja visión: tenía espacios donde se realizaban siempre las mismas actividades y los materiales se mantenían en el mismo orden. Fue interesante mantener un rincón donde el alumno en concreto se podía sentir seguro y tranquilo, por lo que se colocaron una alfombra y unos cojines para poder estar más cómodos. En este lugar se trabajaba el ajuste personal o los sentimientos, de modo que resultó un acierto ponerlo ahí.

\section{Recursos personales}

Es indispensable hablar de los recursos personales. En la justificación se ha comentado que el asesoramiento del Creena fue uno de los elementos que ha hecho más eficaz esta intervención. También ha ayudado el apoyo obtenido en la UAE por parte de la orientadora, sobre todo a la hora de tomar decisiones respecto al material de enseñanza o el refuerzo a utilizar, o con temas de ajuste personal.

Pero, tan importante como esto, ha sido la coordinación entre tutor y profesora de apoyo. Una sesión de cada mes, cada vez que se terminaba una unidad didáctica o un proyecto, la tutora y la profesora de apoyo se reunían para poder programar y organizar las actividades o los ejercicios, poder hacer las adaptaciones pertinentes, poder valorar la evolución del niño o las actividades de inclusión o ajuste personal realizadas, siendo muy importante este trabajo conjunto.

Destacar la implicación de los progenitores del niño con discapacidad en esta aula. Fueron de gran ayuda las recomendaciones obtenidas de Bueno (1999). Es el tercer curso que el alumno con baja visión lleva en el centro, y el niño está incluido tanto dentro de la clase como en la calle. 
Han sido una actividad muy valiosa de sensibilización los vídeos grabados y mostrados a las demás familias del aula sobre el grupo de actividades número 2, para conocer mejor y entender mejor a esta población. Las valoraciones fueron positivas.

\section{Recursos de nuevas tecnologías}

Es otro de los descubrimientos o novedades de este curso. El colegio lleva dos años en un programa para integrar las tecnologías de la información y la comunicación (TIC) en el aula: Samsung Smart School. Este ofrece la posibilidad de que el alumnado disponga de una tableta.

La tableta es táctil y, mediante ajustes, se puede personalizar mucho para que el alumno pueda ver mejor y evitar mucha fatiga visual. Contiene también un lápiz, un programa específico para la escritura y el dibujo, voz y acceso a internet.

En base a la experiencia desarrollada, sería un error no utilizar este recurso en el aula pues, no solo ayuda a conseguir el objetivo 10 , sino que también proporciona accesibilidad a la información, fomenta la lectura y la escritura, y ayuda al niño a participar de forma activa y autónoma en su propio aprendizaje sin fatiga visual (una vez que adquiere destreza, que, en este caso, fue en un plazo breve).

Además, el Creena siempre ha tenido en cuenta las nuevas tecnologías con el mismo objetivo, y ha ido asesorando teniendo en cuenta la evolución del alumno (García, 2017).

\section{Resultados}

El efecto final de esta actuación ha sido, para los agentes que han intervenido (alumno, profesora de apoyo, tutora, padre, madre, miembros del Equipo Específico de Discapacidad Visual), muy positivo.

Las evidencias de esos resultados se han conseguido de forma más objetiva mediante las hojas de registro de los objetivos del plan de trabajo y los boletines. Pero, sobre todo, se han recogido mediante la observación, las valoraciones de los agentes que han trabajado con él, teniendo en cuenta la eficacia de las actividades en la consecución de los objetivos. 
El $60 \%$ de los materiales y el $76 \%$ de las actividades son muy adecuadas, creativas y novedosas. De las 11 actividades mencionadas, se han valorado 8 por parte del Creena y de la UAE de forma muy positiva.

El $23 \%$ de las actividades se pueden mejorar, y el $20 \%$ de los materiales también. Un $3 \%$ se debería utilizar muy poco. Esta valoración se ha realizado de forma cualitativa también.

Se han cumplido los 10 objetivos propuestos para el plan de trabajo. Sin embargo, hay algunos aspectos a mejorar, sobre todo, en el ritmo de lectura en tinta (es más lento que el del resto de sus compañeros, pero es una característica de su baja visión) y en el desarrollo de las habilidades hápticas: todavía al alumno le cuesta detectar o leer en braille en ciertos materiales (necesita soportes con cajetines o puntos muy marcados).

En el Apéndice $C$ se recoge la valoración general de las actividades y materiales por todos los agentes que intervienen, teniendo en cuenta la utilidad para conseguir los objetivos marcados. Dichas valoraciones se expresan mediante un código de 3 colores: verde, que significa muy útil y positiva; naranja, positiva, pero mejorable, y rojo, necesita mejorarse.

\section{Conclusiones}

Con este plan de trabajo, se esperaba dar una buena respuesta educativa a un niño con discapacidad visual que ya era conocido en el centro, en Educación Infantil, del cual se sabía que le esperaba, por una parte, un primer curso de Educación Primaria con muchos contenidos y competencias que aprender, $y$, por la otra, un proceso de alfabetización (primera y segunda fases) en tinta y braille que llevar a cabo con eficacia y la menor fatiga posible. Esta fatiga se podría producir por muchos contenidos extras más que se debían trabajar: habilidades hápticas, motrices, retener experiencias con los cinco sentidos, conocer el alfabeto braille, conseguir un ajuste personal y social a la discapacidad adecuado y equilibrado, etc.

Sin duda, el Creena ha jugado un papel muy importante en el asesoramiento y guía de trabajo hacia la profesora de apoyo, pero los resultados conseguidos también han sido fruto de la buena coordinación de la UAE, la tutora y el padre y la madre del

Urdangarin, O. (2020). Conjunto de actividades basadas en el desarrollo multisensorial y la alfabetización en braille y tinta para favorecer la inclusión educativa en Primaria de un alumno con discapacidad visual. RED Visual: Revista Especializada en Discapacidad Visual, 76, 115-148. https://doi.org/10.53094/OSKU2586. 
alumno del Colegio Público San Donato de Navarra. Al final, todos los componentes se han implicado y se ha conseguido llevar a cabo esta tarea tan difícil pero tan gratificante a la vez.

Este es un plan de trabajo con mucha implicación emocional por parte de todos los agentes que han intervenido, donde jugar, pillar por sorpresa, emocionar, apoyar, retar y divertirse aprendiendo han ayudado a motivar, a seguir adelante pese a la fatiga, pese al tropezón.

Unos materiales y actividades creativos y con elementos a mejorar y propuestas, para que quien lo utilice lo pueda reutilizar de forma más efectiva aún. Además, aporta flexibilidad, porque el profesor puede elegir el tipo de actividad o material que quiere trabajar teniendo en cuenta las necesidades y la programación didáctica ofrecida.

Unas experiencias inclusivas y de ajuste personal y social con unas pautas de actuación claras para poder llevar a cabo. Estas experiencias han enseñado a los agentes implicados que es muy importante que la comunidad educativa pueda ver y pueda experimentar lo que el niño con discapacidad visual vive, y es muy importante que los niños con discapacidad visual puedan compartir con los demás lo que han aprendido, lo que pueden hacer. Se enriquecen muchas habilidades para la convivencia: escucha activa, empatía, reflexión sobre emociones, aceptación de emociones, aceptarse tal y como se es, resolver los conflictos desde el respeto, entender y respetar que todos son diferentes, etc.

Una valoración de resultados objetiva y más cualitativa que cuantitativa, que puede ayudar a orientar en la selección de actividades y materiales para conseguir los objetivos expuestos teniendo en cuenta la edad y sus destrezas.

En definitiva, este plan de trabajo cumple con los requisitos básicos marcados por el Ministerio de Educación y Formación Profesional para poder ser una buena práctica con niños de baja visión y/o con un pronóstico similar: es innovadora, efectiva, sostenible y replicable.

\section{Referencias bibliográficas}

Albertí, M., y Romero, L. (2010). Alumnado con discapacidad visual. Barcelona, España: Graó.

Urdangarin, O. (2020). Conjunto de actividades basadas en el desarrollo multisensorial y la alfabetización en braille y tinta para favorecer la inclusión educativa en Primaria de un alumno con discapacidad visual. RED Visual: Revista Especializada en Discapacidad Visual, 76, 115-148. https://doi.org/10.53094/OSKU2586. 
Bueno, M. (1999). Niños y niñas con baja visión: recomendaciones para la familia y la escuela. Málaga, España: Aljibe.

Cauto Barros, M. C. (coord.) (2016). La inclusión educativa del alumnado con discapacidad visual [PDF]. Vitoria-Gasteiz, España: Servicio Central de Publicaciones del Gobierno Vasco.

Centro de Recursos de Educación Especial de Navarra [Creena] (2020). Equipo de visuales [página web]. Recurso web.

Comisión Braille Española (2015). La didáctica del braille más allá del código: nuevas perspectivas en la alfabetización del alumnado con discapacidad visual [PDF]. Madrid, España: Organización Nacional de Ciegos Españoles.

García, J. (2017). Acceso a las TIC para alumnos con discapacidad visual [página web]. En: A. Galisteo y M. C. Gálvez (coords.), Accesibilidad, TIC y educación, recurso web.

Instrumento de Ratificación de la Convención sobre los derechos de las personas con discapacidad, hecho en Nueva York el 13 de diciembre de 2006 [PDF] (2008). Boletín Oficial del Estado, 96, de 21 de abril de 2008, 20648-20659.

Lera, M.J. (coord.) (2009). Golden5: una intervención psicoeducativa. Sevilla, España: Servicios de Publicaciones de la Universidad de Sevilla. Recurso web: http://www. golden5.org/golden5/.

Ley Orgánica 2/2006, de 3 de mayo, de Educación [PDF]. Boletín Oficial del Estado, 106, de 4 de mayo de 2006, 17158-17207.

Ley Orgánica 8/2013, de 9 de diciembre, para la mejora de la calidad educativa [PDF]. Boletín Oficial del Estado, 295, de 10 de diciembre de 2013, 97858-97921.

Organización Nacional de Ciegos Españoles (2018). Braitico: método braille de la ONCE para la alfabetización y competencia lectoescritora. Módulo 3: Brailleo. Aprendo a leer y escribir en braille: guía didáctica [PDF]. Madrid, España: Organización Nacional de Ciegos Españoles.

Organización Nacional de Ciegos Españoles (2020a). Braitico [página web]. Recurso web.

Urdangarin, O. (2020). Conjunto de actividades basadas en el desarrollo multisensorial y la alfabetización en braille y tinta para favorecer la inclusión educativa en Primaria de un alumno con discapacidad visual. RED Visual: Revista Especializada en Discapacidad Visual, 76, 115-148. https://doi.org/10.53094/OSKU2586. 
Organización Nacional de Ciegos Españoles (2020b). Recursos educativos: cuentos y juegos [página web]. Recurso web.

Organización Mundial de la Salud (2018). Ceguera y discapacidad visual [página web]. Recurso web.

Salabert, M., y Pallero, R. (2003). El proceso de ajuste a la discapacidad visual. En: J. Checa, P. Díaz y R. Pallero (coords.), Psicología y ceguera: manual para la intervención psicológica en el ajuste a la deficiencia visual [Word] (pp. 45-97). Madrid, España: Organización Nacional de Ciegos Españoles.

Sánchez, M. (2015). Baja visión y discapacidad visual [página web]. Recurso web.

Sánchez Sánchez, M.P. (2005). La lecto-escritura en tinta en alumnos con baja visión: orientaciones didácticas [Word]. Integración: revista sobre ceguera y deficiencia visual, 44, 23-29.

Silberg, J. (2006). Juegos para aprender y estimular los sentidos. Barcelona, España: Oniro.

Spitzer, M. (2005). Aprendizaje: neurociencia y la escuela de la vida. Madrid, España: Omega.

Unicef (2006). Convención sobre los derechos del niño [PDF]. Madrid, España: Unicef Comité Español.

Oihana Urdangarin Iriarte. Profesora de Pedagogía Terapéutica. Colegio Público San Donato. Utzubar txiki, s/n; 31840 Echarri-Aranaz (Navarra, España). Correo electrónico: ourdanga@ educacion.navarra.es.

Urdangarin, O. (2020). Conjunto de actividades basadas en el desarrollo multisensorial y la alfabetización en braille y tinta para favorecer la inclusión educativa en Primaria de un alumno con discapacidad visual. RED Visual: Revista Especializada en Discapacidad Visual, 76, 115-148. https://doi.org/10.53094/OSKU2586. 


\section{Apéndice A}

\section{Plan de trabajo: objetivos, actividades, sesiones y aula}

\begin{tabular}{|c|c|c|}
\hline Objetivos & Actividades & Aula/sesiones \\
\hline $\begin{array}{l}\text { 9. Avanzar en la adquisición } \\
\text { de las competencias que } \\
\text { corresponden para su } \\
\text { edad. Adaptaciones. }\end{array}$ & $\begin{array}{l}\text { - Adaptaciones de acceso al recinto } \\
\text { escolar: líneas amarillas pintadas } \\
\text { en los escalones. } \\
\text { - Adaptaciones de acceso a la infor- } \\
\text { mación en el aula: ubicación del } \\
\text { niño delante de la pizarra. } \\
\text { - Adaptaciones del material escolar: } \\
\text { crear espacios más amplios para } \\
\text { escribir en el libro. }\end{array}$ & $\begin{array}{l}\text { Sala de profesorado } \\
\text { ( } 2 \text { sesiones indirectas } \\
\text { semanales). }\end{array}$ \\
\hline $\begin{array}{l}\text { 7. Avanzar en el desarrollo } \\
\text { emocional y el ajuste per- } \\
\text { sonal y social. }\end{array}$ & $\begin{array}{l}\text { - Tengo miedo a los pollitos. } \\
\text { - No me gusta la oscuridad. } \\
\text { - En la hora del recreo me quedo } \\
\text { solito. }\end{array}$ & $\begin{array}{l}\text { Aula ordinaria } \\
\text { de Educación Primaria } \\
\text { (según surjan). }\end{array}$ \\
\hline $\begin{array}{l}\text { 8. Sensibilizar y hacer partí- } \\
\text { cipe a la comunidad edu- } \\
\text { cativa de los logros y las } \\
\text { dificultades de esta pobla- } \\
\text { ción de forma inclusiva. } \\
\text { 9. Avanzar en la adquisición } \\
\text { de las competencias que } \\
\text { corresponden para su } \\
\text { edad. Reforzar. }\end{array}$ & $\begin{array}{l}\text { - Experimentamos con las gafas. } \\
\text { - Taller de los sentidos. } \\
\text { - Brailleando. } \\
\text { - Tareas que la tutora vea nece- } \\
\text { sarias realizar (de refuerzo o las } \\
\text { ordinarias). } \\
\text { - Lectura y escritura (Guberina). } \\
\text { - Aprendiendo matemáticas. }\end{array}$ & $\begin{array}{l}\text { Aula de apoyo y patio } \\
\text { ( } 3 \text { sesiones directas } \\
\text { anuales, una al final } \\
\text { del trimestre). }\end{array}$ \\
\hline
\end{tabular}

Urdangarin, O. (2020). Conjunto de actividades basadas en el desarrollo multisensorial y la alfabetización en braille y tinta para favorecer la inclusión educativa en Primaria de un alumno con discapacidad visual. RED Visual: Revista Especializada en Discapacidad Visual, 76, 115-148. https://doi.org/10.53094/OSKU2586. 


\begin{tabular}{|c|c|c|}
\hline Objetivos & Actividades & Aula/sesiones \\
\hline $\begin{array}{l}\text { Primera sesión: } \\
\text { 1. Desarrollar el resto visual. } \\
\text { 2. Desarrollar los demás } \\
\text { sentidos, experimentar } \\
\text { con ellos. } \\
\text { 5. Aprender letra a letra la } \\
\text { lectoescritura en tinta. } \\
\text { 6. Aprender letra a letra la } \\
\text { lectoescritura en braille. } \\
\text { Segunda sesión: } \\
\text { 3. Desarrollar la percepción } \\
\text { háptica y la motricidad } \\
\text { fina. } \\
\text { 4. Desarrollar algunos pre- } \\
\text { rrequisitos para el braille. } \\
\text { 6. Aprender letra a letra la }\end{array}$ & $\begin{array}{l}\text { - EVo y Efivis. } \\
\text { - Disparates y láminas de observa- } \\
\text { - Memorys de imágenes. } \\
\text { - Material manipulativo de formas } \\
\text { y colores. } \\
\text { - Juegos de imitación. } \\
\text { - Juegos para experimentar los } \\
\text { - sentidos. } \\
\text { - Caja de las letras. } \\
\text { - Tablillas de letras y números. } \\
\text { - Guberina (letra y gesto). } \\
\text { - Carpeta de coches y monstruos. } \\
\text { - La muñeca Braillina. } \\
\text { - Máquina Perkins. } \\
\text { - Materiales de Braitico (Palabritas } \\
\text { y Contando). }\end{array}$ & $\begin{array}{l}\text { Aula de apoyo } \\
\text { ( } 2 \text { sesiones directas } \\
\text { semanales). }\end{array}$ \\
\hline Todas las sesiones. & $\begin{array}{l}\text { - La caja de sorpresas. } \\
\text { - La bandeja de los tesoros. } \\
\text { - Cuentos y láminas caseras. } \\
\text { - Circuitos y ejercicios de Educación } \\
\text { Física. } \\
\text { - Estrategias de seguridad para } \\
\text { moverse. } \\
\text { - El Braille (libro de la huevera). } \\
\text { - La pulga Leocadia, cuento escrito } \\
\text { en braille. } \\
\text { - Maripoints (Braitico). } \\
\text { - Alfabeto braille (Braitico). } \\
\text { - Carpeta de coches y monstruos } \\
\text { azules. } \\
\text { - Conozcamos a Perkins. }\end{array}$ & $\begin{array}{l}\text { Aula de apoyo } \\
\text { y psicomotricidad. }\end{array}$ \\
\hline $\begin{array}{l}\text { 10. Gestionar la fatiga y la } \\
\text { implicación emocional, } \\
\text { «Estimular sin saturar. } \\
\text { Ayudar sin invadir». }\end{array}$ & $\begin{array}{l}\text { - Actividades para elegir. } \\
\text { - Jugamos a... } \\
\text { - Retos. }\end{array}$ & Todas. \\
\hline
\end{tabular}

Urdangarin, O. (2020). Conjunto de actividades basadas en el desarrollo multisensorial y la alfabetización en braille y tinta para favorecer la inclusión educativa en Primaria de un alumno con discapacidad visual. RED Visual: Revista Especializada en Discapacidad Visual, 76, 115-148. https://doi.org/10.53094/OSKU2586. 


\section{Apéndice B \\ Materiales para realizar actividades}

\section{Materiales para las actividades de ajuste personal y desarrollo emocional (Cuadro 1)}

- Documentación y formación recibida por el Equipo Específico de Visuales sobre el ajuste personal.

- Documento aportado por el equipo específico, en el que se presentan juegos con linterna y estrategias para moverse en la oscuridad.

- 3 juegos para vencer el miedo a la oscuridad de tu hijo [página web].

- Una caja y un pollito.

- Un cascabel, material para hacer sombras chinescas.

- Móvil o tableta para grabar y sacar fotos.

- Unos petos de colores vivos para que el alumno detecte mejor a sus compañeros en el recreo.

- Linterna con distintas imágenes para proyectar en la pared.

\section{Materiales para las actividades que favorecen la inclusión (Cuadro 2)}

- Moldura de gafas que no se utilizan; plásticos y plastificadora para crear las lentes, cartulina negra... También accesibles las del equipo específico.

- Materiales necesarios para hacer experimentos con los sentidos.

- Jackie Silberg (2006), Juegos para aprender y estimular los sentidos; Oniro.

- Estimulación sensorial «El mundo por los sentidos» [página web]. 
- Materiales y estrategias aportados por el equipo específico de percepción háptica.

- Material Braitico (muy recomendable, porque se pueden percibir muy claramente los puntos de forma táctil), otros materiales manipulativos (huevera, Maripoints, máquina Perkins, papel, nombres de los de clase en braille, la muñeca Braillina, carpeta de coches y monstruos), libro que explica lo que es el braille (muy recomendable), el cuento de La pulga Leocadia (Organización Nacional de Ciegos, 2020a; 2020b).

\section{Materiales para las actividades de estimulación visual (Cuadro 3)}

- Caja de láminas: láminas visuales, algunas de estas láminas están relacionadas con el tema de ciencias que se han trabajado en el curso (Mimontessori y nuestra forma de compartirlo [página web], categoría Ciencia).

- Láminas absurdas: Absurdos visuales [página web], en el blog Mis materiales AL y PT.

- Juegos de cartas: Juegos de memoria o Memorama para imprimir [página web], en la web Memojuegos; 4 juegos de memoria para imprimir gratis [página web], en la web Pequeocio.

- Pinzas de colores, caja, papel de colores: La caja de las pinzas y sus colores [página web], de Covadongamora, en el blog Paperblog.

- Palillos, plastilina, palos de polo y velcro: Figuras con palillos y plastilina [imagen web] en el blog Blog de Sexto C; Geometría con palitos de helado [página web], en la web Aprendiendo matemáticas.

\section{Materiales para las actividades de estimulación sensorial (Cuadro 4)}

- Jackie Silberg (2006), Juegos para aprender y estimular los sentidos; Oniro.

- Estimulación sensorial «El mundo por los sentidos» [página web].

- Buscando en Google el sentido que deseas estimular, puedes encontrar material muy recomendable: por ejemplo, para buscar material relativo a la estimulación auditiva o discriminación auditiva. 


\section{Materiales para las actividades de estimulación de la percepción háptica (Cuadro 5)}

- Caja de sorpresas.

- Fichas de Lego Duplo y fichas de Lego Junior.

- Otros juguetes o elementos reales organizados según el proyecto trabajado en Ciencias Naturales y Sociales.

- Materiales diversos para rellenar la caja relacionados con el proyecto trabajado en Ciencias Naturales y Sociales.

- Bandejas para guardar los tesoros.

- Pósits de colores, bolígrafos o pequeñas figuritas, chucherías... (Los tesoros).

- Diferentes productos para rellenar la bandeja (sal, azúcar, harina, leche, agua, gelatina...).

\section{Materiales para las actividades de motricidad fina1: libros y láminas táctiles (Cuadro 6)}

- Todo tipo de material de papelería.

- Material reciclable.

- Material para hacer manualidades.

- Para realizar el teatro de sombras: DIY: hacemos un teatro de sombras [página web], en el blog Club Peques Lectores.

- Para realizar todo tipo de material para reforzar matemáticas, pero también puede servir para trabajar la motricidad: Matemáticas creativas, fáciles y divertidas [página web], en el blog Aprendiendo matemáticas. 


\section{Materiales para las actividades para el aprendizaje de lectoescritura en tinta y braille (Cuadro 7)}

- Caja con tapa transparente para que, una vez que se cierra, se mire, pero no se toque.

- Pósits o papeles y celo.

- Objetos: imágenes de cosas.

- Coches: cartulina de colores, tapones, papeles con distintas texturas, goma EVA, alambre moldeable, tijeras, cola, etc.

- Monstruos azules: cartulina azul, ojos de plástico que se mueven y cola.

- Carpeta, pizarra, sobres, etc.

- Libro braille Miniforms, Braillín, Maripoints, máquina Perkins.

- Gestos Guberina.

- Braitico: Palabritas y Contando.

\section{Imágenes de algunos de los materiales empleados en las actividades}

Figura 1. Linterna mágica con cuatro lentes diferentes

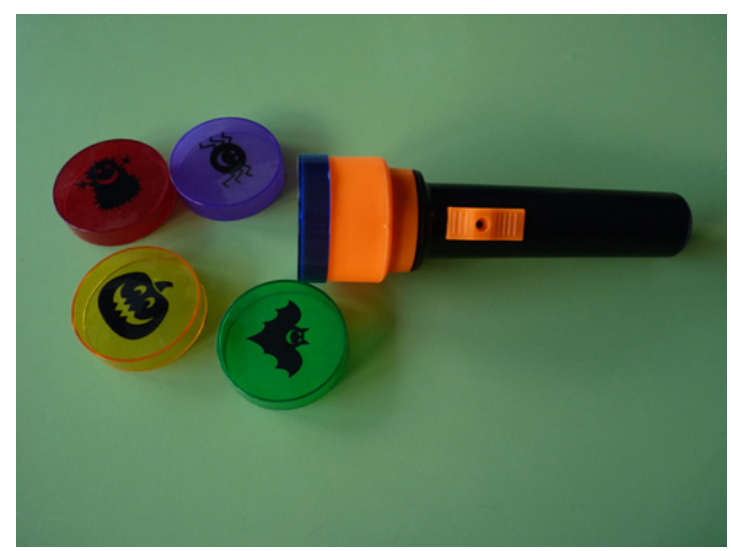

Urdangarin, O. (2020). Conjunto de actividades basadas en el desarrollo multisensorial y la alfabetización en braille y tinta para favorecer la inclusión educativa en Primaria de un alumno con discapacidad visual. RED Visual: Revista Especializada en Discapacidad Visual, 76, 115-148. https://doi.org/10.53094/OSKU2586. 
Figura 2. Libros táctiles de la ONCE

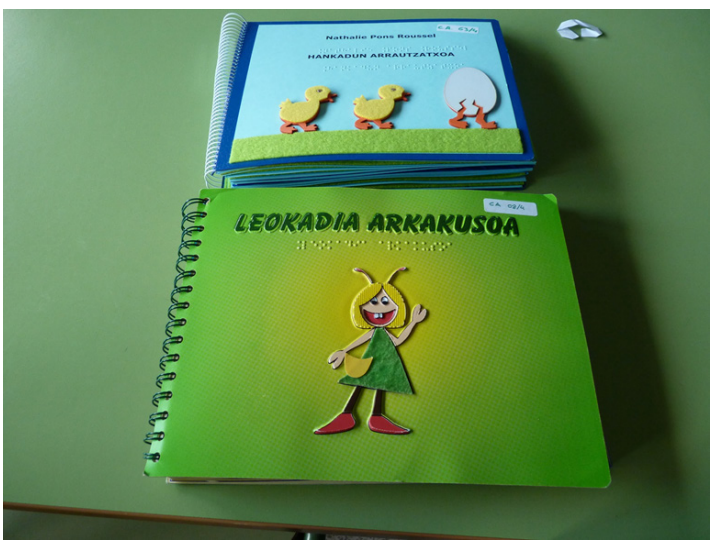

Figura 3. Caja mágica y construcción

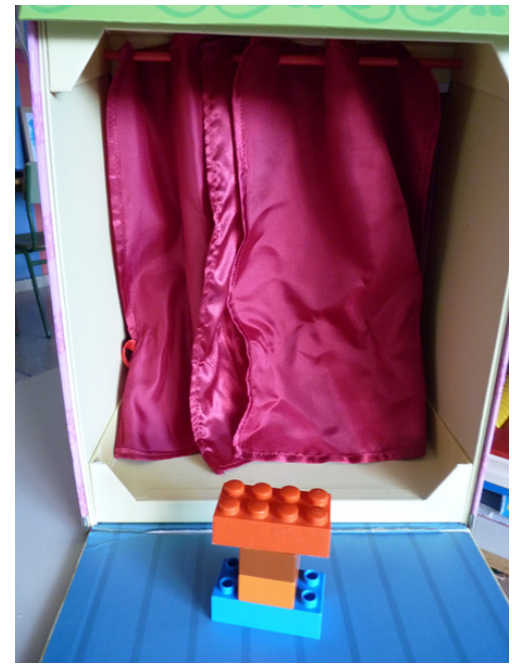

Figura 4. Láminas táctiles creadas por el alumno para explicar la vida en la Prehistoria

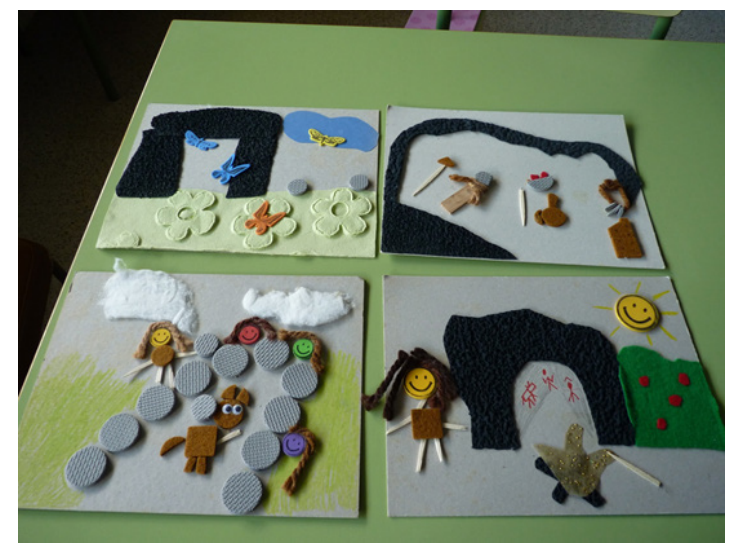

Urdangarin, O. (2020). Conjunto de actividades basadas en el desarrollo multisensorial y la alfabetización en braille y tinta para favorecer la inclusión educativa en Primaria de un alumno con discapacidad visual. RED Visual: Revista Especializada en Discapacidad Visual, 76, 115-148. https://doi.org/10.53094/OSKU2586. 
Figura 5. Láminas táctiles creadas por el alumno para explicar el cuerpo humano: esqueleto y órganos

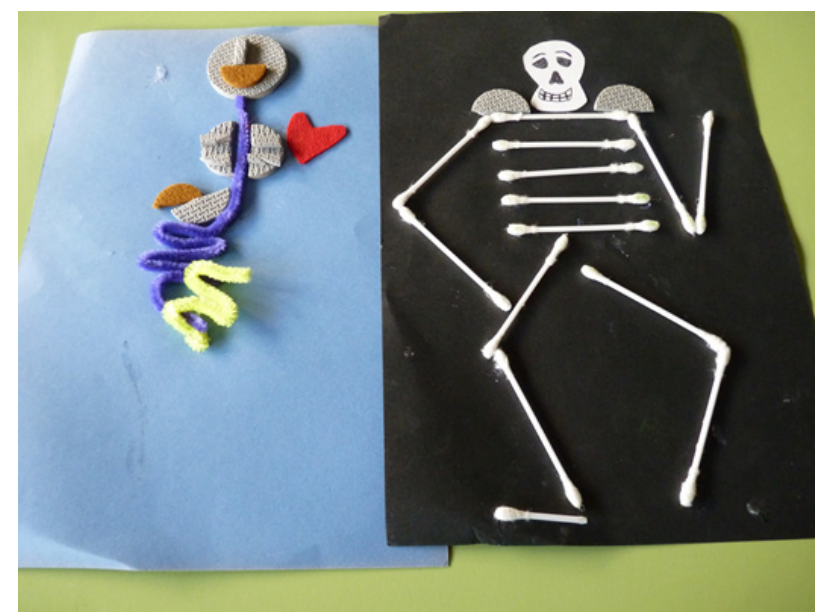

Figura 6. Letras de braille en forma de coches o monstruo de ojos

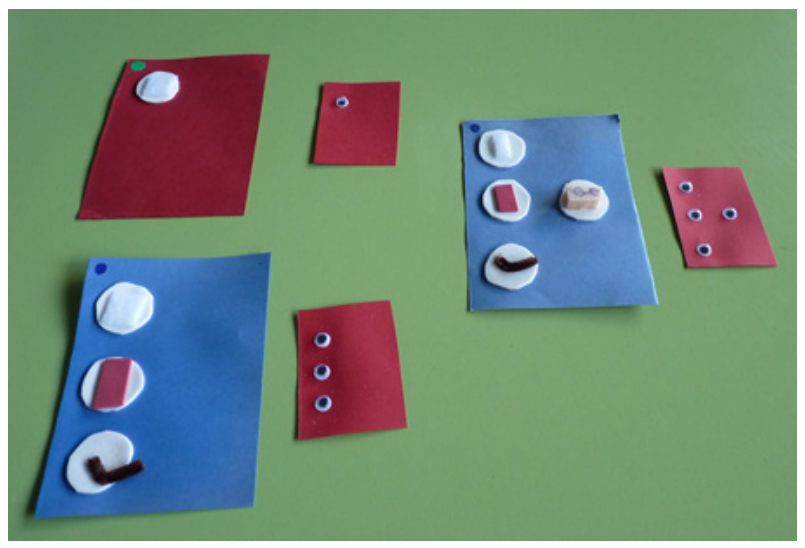

Urdangarin, O. (2020). Conjunto de actividades basadas en el desarrollo multisensorial y la alfabetización en braille y tinta para favorecer la inclusión educativa en Primaria de un alumno con discapacidad visual. RED Visual: Revista Especializada en Discapacidad Visual, 76, 115-148. https://doi.org/10.53094/OSKU2586. 


\section{Apéndice C}

\section{Valoración de actividades y materiales}

\section{Valoración cualitativa de las actividades}

Verde $=$ Muy útil y positiva $/$ Naranja $=$ Positiva, pero mejorable $/$ Rojo $=$ Necesita mejorarse .

\begin{tabular}{|c|c|c|}
\hline Actividad & Valor & Notas \\
\hline 1. Adaptaciones de acceso. & & $\begin{array}{l}\text { + Se valora de forma muy positiva la visita y la } \\
\text { documentación que aporta el equipo específico } \\
\text { al centro para guiar estas adaptaciones. }\end{array}$ \\
\hline $\begin{array}{l}\text { 2. Tengo miedo a los pollitos. } \\
\text { 3. No me gusta la oscuridad. }\end{array}$ & & $\begin{array}{l}\text { - Parten de miedos que, a veces, no son generali- } \\
\text { zables. } \\
\text { + Destacar el método para poder guiar el ajuste } \\
\text { personal del niño ofrecido por equipos específi- } \\
\text { cos. }\end{array}$ \\
\hline $\begin{array}{l}\text { 4. En la hora del recreo me } \\
\text { quedo solito. }\end{array}$ & & $\begin{array}{l}\text { + Se trata de un problema más generalizado } \\
\text { en esta población. } \\
\text { + Destaca el método de ajuste personal. }\end{array}$ \\
\hline $\begin{array}{l}\text { 5. Experimentamos con las } \\
\text { gafas. }\end{array}$ & & $\begin{array}{l}\text { + La experiencia ha ayudado a ponerse en el lugar } \\
\text { de la otra persona. } \\
\text { + Muy importante la puesta en común o la } \\
\text { reflexión final. }\end{array}$ \\
\hline 6. Taller de los sentidos. & & $\begin{array}{l}\text { + Experimentar motiva, para los demás fue una } \\
\text { recompensa. Para el alumno fue una actividad } \\
\text { de éxito porque se había entrenado mucho. }\end{array}$ \\
\hline 7. Brailleando. & & $\begin{array}{l}\text { - Mucho material para tocar y algunos alumnos } \\
\text { tenían falta de control para esperar a las } \\
\text { explicaciones. Puede salir algo caótico. }\end{array}$ \\
\hline $\begin{array}{l}\text { 8. Tareas que la tutora vea } \\
\text { necesarias realizar (de re- } \\
\text { fuerzo). }\end{array}$ & & $\begin{array}{l}\text { + Utilizar material manipulativo o las TIC para } \\
\text { motivar al alumnado. } \\
+ \text { A veces adelantarnos crea placer en el niño y } \\
\text { vivir una situación de éxito. }\end{array}$ \\
\hline $\begin{array}{l}\text { 9. Editar videos de las ex- } \\
\text { periencias vividas por el } \\
\text { grupo-clase y mostrar a los } \\
\text { padres. }\end{array}$ & & $\begin{array}{l}\text { + Positivo, los padres entienden que con estas } \\
\text { experiencias también se aprende y valoran } \\
\text { mejor la atención a la diversidad. }\end{array}$ \\
\hline
\end{tabular}

Urdangarin, O. (2020). Conjunto de actividades basadas en el desarrollo multisensorial y la alfabetización en braille y tinta para favorecer la inclusión educativa en Primaria de un alumno con discapacidad visual. RED Visual: Revista Especializada en Discapacidad Visual, 76, 115-148. https://doi.org/10.53094/OSKU2586. 


\begin{tabular}{|c|c|c|}
\hline Actividad & Valor & Notas \\
\hline $\begin{array}{l}\text { 10. Editar videos del trabajo } \\
\text { diario en el aula de } \\
\text { apoyo con el alumno } \\
\text { de baja visión. }\end{array}$ & & $\begin{array}{l}\text { + Se aprecian y valoran mejor los logros y se } \\
\text { entienden mejor las dificultades. Ayudan a } \\
\text { aceptar las dificultades por parte de los padres. } \\
\text { + Para los profesionales es muy gratificante verlo. } \\
\text { + Ayuda a veces a retroalimentar y a reorientar } \\
\text { la práctica. } \\
\text { + Ayuda a veces a retroalimentar y a reorientar } \\
\text { la práctica educativa. }\end{array}$ \\
\hline $\begin{array}{l}\text { 11. Crear actividades } \\
\text { y circuitos para trabajar } \\
\text { la motricidad gruesa y la } \\
\text { seguridad en movilidad. }\end{array}$ & & $\begin{array}{l}\text { + Se valoran de forma muy positiva todas aquellas } \\
\text { actividades que fomenten la seguridad en movilidad. } \\
+ \text { Se recomienda asesoramiento por parte del } \\
\text { técnico de la onCE y coordinación con la } \\
\text { profesora de Educación Especial. }\end{array}$ \\
\hline
\end{tabular}

\section{Valoración cualitativa de los materiales utilizados}

Verde $=$ Muy útil y positiva $/$ Naranja $=$ Positiva, pero mejorable $/$ Rojo $=$ Necesita mejorarse .

\begin{tabular}{|c|c|c|}
\hline Material & Valor & Notas \\
\hline $\begin{array}{l}\text { 1. Programas informáticos: } \\
\text { EVo/Efivis para estimular } \\
\text { el resto visual. }\end{array}$ & & $\begin{array}{l}\text { + Material informático que puede aportar a } \\
\text { utonomía al hacerlo, puesto que son actividades } \\
\text { repetitivas. } \\
\text { - Hay que utilizar durante poco tiempo, pero de } \\
\text { forma muy sistemática. El alumnado se aburre. } \\
\text { - Leerse bien los manuales para poder aprovechar } \\
\text { al máximo los ejercicios. Probarlo de antemano. }\end{array}$ \\
\hline $\begin{array}{l}\text { 2. } \\
\text { - Disparates y láminas } \\
\text { de observación. } \\
\text { - Memories de imágenes. } \\
\text { - Material manipulativo de } \\
\text { - Jormas y colores. } \\
\text { - Juegos de imitación. }\end{array}$ & & $\begin{array}{l}\text { + Estas actividades se deben organizar alternando } \\
\text { unas y otras y de vez en cuando. } \\
\text { - Les cuesta mucho realizar las } 2 \text { primeras } \\
\text { y habría que especificar niveles de dificultad. }\end{array}$ \\
\hline $\begin{array}{l}\text { 3. Juegos para desarrollar } \\
\text { los sentidos. }\end{array}$ & & $\begin{array}{l}\text { + Actividades muy placenteras. } \\
\text { + Prepararlas de antemano. }\end{array}$ \\
\hline 4. Caja de las letras. & & $\begin{array}{l}\text { + Muy recomendable si lo unimos con las } \\
\text { bandejas de textura. } \\
+ \text { Se enriquece el vocabulario. } \\
+ \text { Se favorece la lectura y escritura. }\end{array}$ \\
\hline
\end{tabular}

Urdangarin, O. (2020). Conjunto de actividades basadas en el desarrollo multisensorial y la alfabetización en braille y tinta para favorecer la inclusión educativa en Primaria de un alumno con discapacidad visual. RED Visual: Revista Especializada en Discapacidad Visual, 76, 115-148. https://doi.org/10.53094/OSKU2586. 


\begin{tabular}{|c|c|c|}
\hline Material & Valor & Notas \\
\hline $\begin{array}{l}\text { 5. Tablillas de letras } \\
\text { y números. }\end{array}$ & & $\begin{array}{l}\text { - Merece la pena utilizar otras actividades } \\
\text { o materiales para trabajar el trazo de las letras. }\end{array}$ \\
\hline 6. Guberina (letra y gesto). & & $\begin{array}{l}\text { + Recomendable no solo para interiorizar } \\
\text { las letras sino también para ayudar a reforzar } \\
\text { los fonemas y evitar dificultades de omisión } \\
\text { o confusión. }\end{array}$ \\
\hline 7. Carpeta de coches. & & $\begin{array}{l}\text { - Material más adecuado para utilizarlo } \\
\text { en Educación Infantil. } \\
\text { + Interiorizan mejor el material porque se les } \\
\text { hace muy cercano. }\end{array}$ \\
\hline $\begin{array}{l}\text { 8. Carpeta de monstruos de } \\
\text { colores. }\end{array}$ & & $\begin{array}{l}\text { + Material que ayuda a acercar al alumno } \\
\text { de Primaria las letras del braille real. }\end{array}$ \\
\hline 9. La muñeca Braillerina. & & $\begin{array}{l}\text { - Material más adecuado para utilizarlo } \\
\text { en Educación Infantil. }\end{array}$ \\
\hline 10. La caja de sorpresas. & & $\begin{array}{l}\text { + Muy recomendable. } \\
\text { + Trabaja la percepción háptica y representacio- } \\
\text { nes mentales (muy útiles para trabajar } \\
\text { el pensamiento abstracto). }\end{array}$ \\
\hline 11. Cuentos y láminas táctiles. & & $\begin{array}{l}\text { + Muy útil para trabajar la motricidad fina } \\
\text { (presión, independencia de dedos, } \\
\text { coordinación...) y la creatividad. } \\
\text { + Da opciones también para trabajar lenguaje oral } \\
\text { y lectoescritura. }\end{array}$ \\
\hline $\begin{array}{l}\text { 12. Libros para la iniciación al } \\
\text { braille } \\
\text { - Alfabeto braille. } \\
\text { - ¿Qué es el braille (libro } \\
\text { de la huevera)? }\end{array}$ & & $\begin{array}{l}\text { - Materiales adecuados para mostrar un poco } \\
\text { para qué sirve el braille y cómo funciona. }\end{array}$ \\
\hline 13. Material Braitico. & & $\begin{array}{l}\text { + Muy recomendable. } \\
\text { + El material con el que está hecho favorece } \\
\text { la percepción háptica, pero también ayuda } \\
\text { a la percepción visual. Es versátil. } \\
\text { + Muy lúdico, con diferentes formas para jugar } \\
\text { (Palabritas y Contamos). } \\
\text { + Muy adecuado para introducir las letras } \\
\text { en español. } \\
\text { - A veces da demasiadas pistas al alumnado que } \\
\text { tiene resto visual. }\end{array}$ \\
\hline
\end{tabular}

Urdangarin, O. (2020). Conjunto de actividades basadas en el desarrollo multisensorial y la alfabetización en braille y tinta para favorecer la inclusión educativa en Primaria de un alumno con discapacidad visual. RED Visual: Revista Especializada en Discapacidad Visual, 76, 115-148. https://doi.org/10.53094/OSKU2586. 


\begin{tabular}{|c|c|c|}
\hline Material & Valor & Notas \\
\hline $\begin{array}{l}\text { 13. La pulga Leocadia y otros } \\
\text { cuentos escritos en braille } \\
\text { y CD con juegos. }\end{array}$ & & $\begin{array}{l}\text { + Muy recomendable. } \\
+ \text { Cuentos en varios idiomas. } \\
+ \text { Cuentos con una historia. } \\
+ \text { cD muy útil para iniciar con la utilización } \\
\text { del ordenador. }\end{array}$ \\
\hline 15. Máquina Perkins. & & $\begin{array}{l}\text { + Muy adecuado para escribir. } \\
\text { - Hace falta mucha fuerza en los niños para poder } \\
\text { escribir. }\end{array}$ \\
\hline 16. Maripoints (Braitico). & & $\begin{array}{l}\text { + Adecuado para Infantil y primer ciclo } \\
\text { de Primaria. } \\
+ \text { Muy adecuado para aprender a colocar } \\
\text { los dedos para escribir en braille. }\end{array}$ \\
\hline 17. La bandeja de los tesoros. & & $\begin{array}{l}\text { + Muy recomendable. } \\
+ \text { El alumno tiene la oportunidad de experimentar } \\
\text { con distintas texturas, aprender a tocar } \\
\text { y a percibir lo que puede ser. } \\
\text { + Motiva mucho y favorece la lectura, sobre todo. }\end{array}$ \\
\hline 18. Miniforms de braille. & & $\begin{array}{l}\text { + Muy adecuado para trabajar la simetría. } \\
\text { - Hay que trabajar al principio de forma } \\
\text { manipulativa para que pueda entender } \\
\text { la simetría en el braille. }\end{array}$ \\
\hline $\begin{array}{l}\text { 19. Material manipulativo para } \\
\text { matemáticas. }\end{array}$ & & $\begin{array}{l}\text { + Es versátil, porque al utilizar material manipula- } \\
\text { tivo da opción a trabajar la percepción háptica. } \\
+ \text { La web Aprendiendo matemáticas o Pinterest } \\
\text { proporcionan muchas ideas. }\end{array}$ \\
\hline
\end{tabular}

